\title{
Editorial
}

\section{Exchange of Information and the OECD Model Treaty}

\author{
J.D.B. Oliver, Coopers \& Lybrand, London
}

The introduction to the publication last year by the OECD of Tax Information Exchange between OECD Member Countries: a survey of current practices described the report as being intended 'to help taxpayers to better understand the operation of the exchange of tax information'. The report acknowledges that an area of particular interest in the last decade has been the relationship between the tax payer and the administration and instances the choice of exchange of information and the protection of confidential information as subjects at the 1990 and 1991 International Fiscal Association Congresses.

The report begins by acknowledging both the narrow interpretation of the clause (that the information which may be exchanged must be for the purpose of applying the convention) and the broad interpretation. An example given of the broad interpretation is the discussion in paragraph 8 of the 1977 Commentary. This gives an example of the exchange of information between States A and B regarding transactions with a company in State $\mathrm{C}$ for the purpose of implementing their domestic law. They exchange information on the prices charged by a company in State $\mathrm{A}$ to the company in State $\mathrm{C}$ and by the company in State $\mathrm{C}$ to the company in State B.

The report goes on to describe the three main forms of exchange (on request, automatic and spontaneous) without going into any greater detail on the justification for the latter two methods, nor indeed the amount of paper which an automatic exchange would tend to generate.

Another part of the report is taken up with the discussion of the relation between the 1963 Draft Convention and the Commentary in the 1977 Model. 'The majority of countries' it reports, 'are of the opinion that the 1977 Commentary is equally applicable to conventions based on the 1963 Draft Convention. Some of these countries, however, make the proviso that in so far as the 1977 Commentary explains new elements incorporated in the article, it is not applicable to the text of Article 26 of the 1963 Draft Convention.' This is an issue which is applicable throughout the Commentary and not just to Article 26. It seems true to say that the precise position will vary from country to country and will in the end depend upon the decisions of the Courts in the relevant country.

The report then moves on to discuss some of the limitations to the exchange of information and in particular those cases where there is a risk of the disclosure of business or professional secrets ('secret or trade process' as Article 26(2)(c) puts it). This is closely connected, though the report itself does not make the connection, to the right of the tax payer to be informed about any proposed exchange because the judgment as to what is a trade or business secret may not best be made by the tax authority. A business secret might typically be thought to take the form of a formula for a particular manufacturing process (i.e. a trade process). Such information however is hardly likely to be of great relevance to the tax authorities except perhaps in some royalty issue. Much more often it may be that what is secret (in the sense that disclosure would damage the business) may be the pricing policy pursued in relation to particular customers or the incurring of particular expenditure, e.g. advertising expenditure. Such information might well be of great value to competitors in the field but this aspect is not something that is likely to be well known to the tax authorities themselves without consultation with the taxpayer. Blandly, the report comments that '.. . it does not seem that the recognition and the protection of trade and business secrets constitute a serious obstacle for the exchange of information. It should be remembered that the requested State is not forced to comply with a request ... the requested State may get in touch with the applicant State in order to establish how the information is to be passed and what protective measures that State has according to its internal provisions, to protect such secrets'. Taxpayers may see it differently. 
On the matter of consultation with the taxpayer, the report notes that: 'There is generally no obligation for the requesting State to notify or consult the taxpayer about a request being sent out to a Treaty partner.... in the majority of countries the requested State also has no obligation to notify the taxpayer or concerned third parties before it requests a response to a request for information from a Treaty partner and in a number of countries, it is at the discretion of the tax administration to notify ... in practice, in all countries the taxpayer is always informed of the exchange when the information received is used to support an adjustment to tax liability.' No doubt this last statement is correct but the stage at which the tax payer is informed may vary and may sometimes be a source of embarrassment or confusion to the taxpayer.

Overall, therefore, the report does not really break any new ground. On a more hopeful note, however, and turning from the OECD Model to the Treaty of Rome and the EU directives, an encouragement for the taxpayer in the field of exchange of information in the past year has come from the Halliburton case. There the Netherlands government contended that the restriction of an exemption to companies constituted under national law was necessary because the administration was unable to check whether the legal forms of entities constituted in other States were equivalent to those of public and private limited companies within the meaning of the relevant national legislation. That argument was rejected by the European Court of Justice on the ground that information pertaining to the characteristics of the forms in which companies may be constituted in other Member States could be obtained through the system provided by the Directive concerning Mutual Assistance by the Competent Authorities of the Member States in the field of direct taxation. This provides an interesting example of exchange of information provisions being used as a shield for the taxpayer instead of a sword for the administration. 